\title{
The physiological construction of the neurone concept (1891-1952)
}

\begin{abstract}
J.G. BARBARA. Université Pierre et Marie Curie.
Neurobiologie des Processus Adaptatifs CNRS UMR 7102. Recherches Epistémologiques et Historiques sur les Sciences Exactes et les Institutions Scientifiques REHSEIS CNRS UMR7596. Case 14, 7 quai Saint Bernard, Paris 75005, France.

E-mail address: Jean-Gael.Barbara@snv.jussieu.fr.
\end{abstract}

\section{Résumé}

Les étapes de la construction physiologique du concept de neurone sont décrites. Les idées initiales sur la fonction de la cellule nerveuse aboutissent aux polémiques sur la théorie du neurone et les prétentions spéculatives de l'histophysiologie. Les programmes de recherche de Sherrington et Adrian émergent d'un contexte britannique spécifique et se confrontent à l'oscillographie américaine et au rythme de Berger. Au terme de polémiques multiples, le neurone se constitue par la technique intracellulaire et l'incorporation de concepts issus d'autres sous-disciplines. L'analyse de ces voies démontre les interactions entre disciplines sous-jacentes comme des facteurs essentiels.

\begin{abstract}
Steps in the physiological construction of the neurone concept are described. Early ideas on the function of the nerve cell led to later polemics on the neurone doctrine and the speculative attitude of histophysiology. Researches of Sherrington and Adrian emerged from a specific British context, and confronted American oscillography and Berger rhythm. At the end of various polemics, the neurone was constructed by the intracellular technique and the use of concepts borrowed from other sub-disciplines. Analysis of these paths demonstrate underlying disciplinary interactions as essential factors.
\end{abstract}

\section{Introduction}

The classical presentation of the
neurone doctrine describes main achievements and controversies over different techniques and interpretations of relations between nerve fibres and the soma of nerve cells. The neurone concept of Heinrich Waldeyer (1836-1921) [1] was established upon a topography of subcellular elements such as dendrites, somata, nuclei, fibrils, and axons (1891).
However, the idea of polarized functional interactions between cell parts allowed a new interpretation of the neurone which emphasized the role of the soma in the propagation of nerve impulse. The success of the neurone doctrine promoted further physiological speculations with marked differences among European countries. The legitimacy of histology to comment on the function of nerve cells seemed to overlap that of physiology. Conversely, physiology interacted with histology, when 
this discipline was able to adopt, criticize and even rectify the neurone concept. However, physiologists differed in this attitude, especially between Britain and France. A comparison of physiological conceptions on nerve cells within particular contexts of reception and rectification of the neurone doctrine is needed. Our goal is to establish how different research programmes devoted to the nervous system emerged at the beginning of the XXth century. An implicit reference to the central role of the nerve cell in some programmes determined original paths in the careers of Charles Sherrington (1857-1952) and Edgar Douglas Adrian (1889-1977). British physiology was more inclined than French or American to localize nervous properties in neuronal elements. Numerous polemics arose between axonolgy, electroencephalography and neurophysiology. Occasionally, they determined heuristic syncretisms between distant research programmes. These events finally led to the modern neurone concept developed with intracellular recordings (1952). This paper aims to examine old rooted epistemological problems which paralleled the construction of the neurone concept from 1891 to 1952. An emphasis is put on the role of pre-established scientific disciplines, sub-disciplines and their relations as important factors contributing to the genesis of epistemological conflicts. Conversely, resolutions and synthesis of different approaches are seen as major determinants of conceptual advances and redefinitions of disciplines. Therefore, the history of the neurone concept gives us the opportunity to ask some intermingled problems between social factors and epistemological knots in examining the relations at work in the constructions of both disciplines and concepts.

\section{Consensus and initial discussions on the nerve cell}

Before the neurone doctrine was established, most physiologists and anatomists held a common view of nerve cells, considered as necessary loci of anatomical interactions between fibres. Such conceptions referred specifically to the soma of cells, located in the grey matter of nerve centres, as opposed to fibres and protoplasmic processes. The nerve cell was occasionally termed "nucleus". In no ways did nerve fibres were understood as parts of nerve cells, although anatomical and functional continuity between them was assumed. Rather, cells were described as enlarged portions of fibres, unipolar, bipolar or multipolar, depending on the number of fibres in contact [2]. Nerve cells were not considered necessary for the transmission of the nervous impulse through ganglia, since most anatomists considered at least some fibres were uninterrupted in crossing these structures. However, multipolar nerve cells in the anterior horn of spinal cord were seen as necessary connecting devices between sensory and motor impulses. In 1857, Claude Bernard (18131878) concluded:

« D'après ce qui précède, on voit que les cellules seraient tantôt l'origine des fibres nerveuses, tantôt des organules placés sur le trajet de ces fibres. On pourrait dans ces cas considérer les tubes comme les conducteurs du système nerveux, dont les cellules seraient l'agent élaborateur ou collecteur. » ([2], pp. 127128)

[From previous facts, [nerve] cells should either be the origin of fibres or organelles placed on fibre paths. In such cases, tubes would represent conductors of the nervous system, with cells being a making or a collecting agent.] 
Occasionally, some histologists and physiologists criticized this simplistic view. The discovery by Louis-Antoine Ranvier (1835-1922) of the T structure of sensory neurones in dorsal root ganglia [3] established a new type of contact between fibres and nerve cells, where the soma could neither be seen necessarily as a collector, nor receptor. The British physiologist Michael Foster (1836-1907) also criticised the role assigned to the soma.

«[... reflex action is carried on undoubtedly through cells. But it does not follow that a cellular mechanism is essential in the sense at all events that the nuclei of the cells have anything to do with the matter $[\ldots] \gg[4]$

Such criticisms were both ancient and common. They supposed functional continuity between fibres only relied on their anatomical continuity, with cells considered as trophic centres. This view was already held by the first French professor of histology at the Parisian Faculté de Médecine, Charles Robin (1821-1885), a famous opponent of cell theory ([5], p. 542). In his work, the exclusion of cells as a general constituent of tissues led to this early form of reticularism (1892).

« Au delà de l'état cellulaire il y a l'état d'organisation ; [...] le mot cellule ne suffit pas, puisqu'il n'implique pas les états de fibre, de tube, états qui sont tout aussi réels que l'état dit cellulaire. » ([5], p. 18)

[Beyond the cellular state lies the state of organization; [...] the word cell does not suffice, since it does not imply states of fibres, tubes which are as real as that termed cellular.]

Conversely, the early cellularist anatomist Mathias Duval (1844-1907), originally from the Strasbourg school of histology, attributed a greater importance to the cell, a view later adopted together with cell theory by Bernard at the Collège de France. Duval stated:

« Le rôle de la cellule nerveuse est de favoriser le passage de l'excitation d'une fibre dans une autre: elle représente un centre de détente; mais ce rôle peut être très complexe ; ainsi souvent un premier globule réfléchit l'action, par une fibre commissure, sur un ou plusieurs autres globules qui peuvent diriger diversement à leur tour, directement sur une fibre centrifuge proprement dite, ou d'abord sur de nouveaux globules nerveux $[\ldots] »([6]$, p. 31)

[The role of the nerve cell is to favour the passage of excitation from a fibre to another: it represents a trigger centre; however this role may be more complex; thus a first globule often reflects action by way of a commissural fibre on one or many globules which diversely direct it on a centrifugal fibre or first on other nervous globules.]

Hence, the first conceptions of the nerve cell as a functional unit were related to the acceptance of cell theory.

However, since physiology was essentially based on the study of nerves, physiologists considered that the anatomical architecture of fibres was a prime structural determinant of function. Accordingly, discussions on the nerve cell remained quite similar to later ones devoted to the neurone concept. Nevertheless, specific reactions to the neurone doctrine in France and Great Britain influenced the debates on the nerve cell and the relations between histology and physiology. Cell theory was no longer crucial to the functional understanding of the neurone, nor in the reception of the neurone doctrine. Rather the institutional 
relations between disciplines became dominant.

\section{The reception of the neurone doctrine among French histologists}

French reception of the neurone doctrine highlights two complex institutional relations between anatomy, anatomopathology and physiology. In the XIX $^{\text {th }}$ century, these disciplines were often associated in teaching, journals and scientific programmes (1). However, at the turn of the $\mathrm{XX}^{\text {th }}$ century, French Bernardian physiology developed into an independent discipline, which increasingly rejected the concepts and methods of anatomy (2). These two aspects permeate and define French reactions to the neurone doctrine.

The first aspect mainly concerns those researchers who were interested both in anatomy, physiology and their relations. The Strasbourg school of histology followed this path before 1870, as it adopted microscopy and cell theory. One of its young most talented scientists Duval took up the chair of Robin (1885). Duval attributed the general success of Santiago Ramón y Cajal's (1852-1934) doctrine, versus the lesser impact of Golgi Camillo's (1843-1926) ideas, to the role generally assigned to nerve cells in physiological studies of spinal cord reflexes ([7], pp. VIII-X). Hence, both physiological and anatomical considerations were present in the early appraisal of Ramón y Cajal's findings and in the adoption of Golgi's method by French histologists, including Duval, Edmond Retterer, Victor André Cornil, Léon Azoulay, Jean Nageotte, Georges Marinseco, and René Legendre.

As many of their European counterparts, French histologists tended to progressively adopt physiological views. The histologist from Nancy Auguste Louis César Prenant (1861-1927) noticed the new physiological orientations of Oscar Hertwig (1849-1922), director of the second Institute of anatomy of the Berlin University in his book La Cellule et les Tissus [8]. Prenant followed this path, when he later discussed histological and physiological views on the role of nerve cells, and sought to define an uneasy consensus [9].

However, some French and Belgium histologists developed, apart from any syncretic position, a style in histophysiology, following Max Schultze (1825-1874), Ranvier, and Ramón y Cajal, but focussing on a cellular approach to processes such as sleep, anaesthesia or memory (Duval, Demoor, Lépine). This perspective was vehemently attacked by physiologists including Kölliker or Lapicque, as stressed by René Legendre (1880-1954):

« [La théorie du neurone] eut un très grand succès $[\ldots]$ elle suscita diverses hypothèses ingénieuses, tant physiologiques que pathologiques et même psychologiques [...] on imagina le point de contact de deux neurones comme un commutateur [...], la commutation étant établie par amœbisme, plasticité ou hypertrophie fonctionnelle [...] Ces théories eurent un grand succès, en France principalement. Cependant elles furent violemment critiquées - avec juste raison - par divers auteurs. [...] ces théories [...] sont en quelque sorte, l'exagération de la théorie du neurone $[\ldots] »([10]$, p. 244)

[The neurone theory had a great success [...] Ingenious physiological, pathological and even psychological hypotheses emerged [...] The point of contact between two neurones was regarded as a switch established by amœbism, plasticity or functional hypertrophy [...] These theories had a great success mainly in France. However, they were vehemently, and 
rightly, attacked by various authors [...] these theories represent some sort of exaggeration of the theory of the neurone. ]

Duval's theory of sleep was the most famous French histophysiological theory [11]. It emerged from the ideas of Hermann Rabl-Rückhard (1839-1905) and contemporary histopathological studies by Raphaël Lépine (1840-1919). It posited that contacts between neurones were less numerous during sleep and reappeared on waking by cell motility. Many histologists considered retraction of neuronal elements only occurred in experimental and pathological conditions and physiologists considered this theory a naïve anatomical determinism of nervous pathways, relying on pure speculations, a view adopted by Ramón y Cajal himself.

However, this radical attitude of French histology reflected the increasing gap between its style of reasoning and that of French physiology, which sought to escape anatomy by any means. This over speculative attitude of part of French histophysiology cannot be seen today as totally naïve or wrong. The finding that the number of dendritic spines was reduced on exposure to toxic agents was generally regarded by contemporaries as a scientifically established fact. However, the absence of direct experimental support for some histophysiological theories such as Duval's contributed to the dismissal of histological approaches by leading French physiologists.

\section{Specificity of the context of reception of the neurone doctrine and its rectification in Great Britain}

As compared to France, British microscopical sciences encompassed a more uniform field of enquiry including anatomopatholgy, comparative histology of plants and animals, human histophysiology, topographic anatomy. It gained full academic recognition with the foundation of the Quarterly Journal of Microscopical Science, founded some 43 years before the French Archives d'Anatomie Microscopique (1897). In Great Britain, cellular theory encountered fewer obstacles than in France, but it was nevertheless criticized in developmental studies [12-14]. In 1891-1892, Golgi's staining method was brought to attention with translated studies from Ramón $\mathrm{y}$ Cajal, Arthur Gehuchten Van (1861-1914), Rudolf Albert von Kölliker (1817-1905) and Luigi Sala (1863-1930) edited in the Journal of Anatomy and Physiology.

However, between 1891 and 1900 few British histologists worked extensively with the new techniques, apart from some observations on invertebrates, neuroglia and ganglionic cells. Rather, the histology of the nervous system was dominated by topographical studies of nerve supplies to organs at a larger scale, emphasizing the gross functional organization of nerves from a physiological perspective. This specific context eventually proved successful in adopting and discussing on solid scientific grounds the neurone doctrine between histological facts and physiological measurements.

This context is highlighted by the famous collaboration between physiologist George Romanes (1848-1894) and histologist Edward Sharpey-Schäfer (18501935). This episode provides an excellent example of British multidisciplinary relations in the context of Foster's young school of physiology, finally permeable to the novel idea that nerve fibres were independent structures functioning physiologically as a whole $[15,16]$. Romanes, one of Foster's first pupils, studied locomotion of jelly fish. He adopted a ganglionic theory close to his master's on heart beat. When he could not localize nervous elements in jelly fish, Romanes asked his friend for help. This 
led Sharpey-Schäfer to discover free fibre endings in the margin of jelly-fish and conclude in favour of physiological continuity of discontinuous fibres [17].

These events were analysed from the standpoint of the neurone doctrine, showing how Sharpey-Schäfer became one of its prominent British forerunners ([15], [16], p. 47). Sharpey-Schäfer himself felt his 1878 paper was the first demonstration of contiguity between nerve cells ([15], p. 160). However, the specificity of the British reception of the neurone doctrine did not rely in Schäfer's discovery, but was shaped by close relations among physiologists and histologists, and the anatomical background of many physiologists. When Sharpey-Schäfer demonstrated free nerve endings in jellyfish, other studies using the gold staining techniques of Julius Cohnheim (18391884) and Joseph von Gerlach (1820-1896) [18] allowed investigators from other countries to clearly refute fibre nets [1921]. Furthermore, the statements of Sharpey-Schäfer on the contiguity of fibres were received sceptically by contemporary reports ([15], p. 160), including one from Romanes. Hence, Sharpey-Schäfer's ideas should not be seen as the "first clear statement of the neurone theory" ([22], p. 246). More important seemed SharpeySchäfer's influence in convincing his friend Romanes, who had initially written critically to Sharpey-Schäfer (1877) ([15], p. 162). For Romanes, physiological continuity of jelly-fish contractile elements was based on coordinated activities of lithocysts, considered as analogous to ganglia. Romanes finally adopted SharpeySchäfer's views, explaining in 1885 his conception of physiological continuity by a "physiological induction" between distinct fibres [23]. Therefore, a continuous and profitable dialogue between physiology and histology seemed possible in Britain, whereas both disciplines were both more specialized and independent in France.
Such relations were pursued during the 1890's between Sherrington, SharpeySchäfer, and Ramón y Cajal. When Sharpey-Schäfer reviewed the neurone doctrine [24], Sherrington was not only concerned with his first physiological studies of spinal cord, but also with anatomopathological and histological observations of fibres, and nerve cells. In 1894, Sherrington invited Ramón y Cajal to give the Croonian Lecture entitled $\mathrm{La}$ fine structure des centres nerveux [25-26]. Much emphasis has been placed on Sherrington's adoption in 1897 of the term synapse [27-28], in the successful confrontation of the histological law of the dynamic polarization of the neurone with recordings of spinal cord antidromic evoked potentials [29]. However, it should be stressed that this adoption did not concern any key discovery, but rather indicated again of a specifically British histological concern in physiology. Berlucchi clearly noted that Sherrington's experimental demonstration of the possibility of antidromic conduction in the spinal cord was based on a refined correlation between possible anatomically defined paths for nervous impulse and their electrophysiological demonstration by precise electrical stimulations [30]. However, experimental antidromic conduction was a rather old theme of nerve physiology, which had inspired work by Emil du Bois-Reymond (1818-1896), Wilhelm Friedrich Kühne (1837-1900), Aleksandr Ivanovich Babukhin [Babuchin] (1835-1891), Edmé Félix Alfred Vulpian (1826-1887) and Paul Bert (1833-1886). In the context of the neurone doctrine, the data from Sherrington clearly showed that the long known physiological polarization of conduction in the spinal cord was not a property of nerve trunks, but rather was localised either in the soma of nerve cells or in theirs junctions with fibres. Berlucchi has pointed out how Ramón y Cajal changed his mind on the polarization of the neurone, finally adopting Sherrington's view ([30], p. 196). Hence, the histological 
orientation of Sherrington and his close contacts with Ramón y Cajal were crucial in the British adoption and rectification of the neurone concept in Britain.

\section{Rejection of the neurone concept as a physiological unit in France (1900)}

Sherrington's personal appraisal of the neurone indicated a new tendency in the 1890s among physiologists to react to a pure histological concept and its histophysiological corollaries. By 1900, physiology was developing new programmes in physical physiology, physiological chemistry both in Britain, France and Germany. Physiology was becoming increasingly emancipated from anatomy. However, if British physiologists retained close links with anatomy, their French counterparts abandoned fundamental studies on reflexes and adopted a physico-chemical approach to life and nerve functions. The career of Albert Dastre (1844-1917), professor of physiology at the Sorbonne, illustrates this orientation. As a student of Bernard, Dastre studied vaso-motor reflexes according to Etienne Jules Marey's (18301904) techniques, before developing chemical analysis of coagulation, liver pigments, or gelatine. Nobel Prize Charles Richet (1850-1935) also abandoned nervous and muscular physiology to adopt a physicochemical programme on stomach secretions, animal heat and serotherapy. Auguste Chauveau (1827-1917) worked on cardiac contraction with Marey before developing in the 1890s energetics as a French physiological discipline.

Consequently, French nervous physiology, while adopting the neurone doctrine, centred both experimental approaches and theoretical interests on the study of nerves, rejecting the neurone as a functional entity of physiological interest. Dastre vividly attacked anatomy and thought the neurone concept was of no utility in the comprehension of the general properties of the nervous system. The nature of the nervous impulse and the determinism of its propagation in various paths should be investigated by physicochemical means. The article published by Jean-Pierre Morat (1846-1920), a collaborator of Dastre and professor of physiology in Lyons, on the nervous system and animal chemistry illustrated this reductionist attitude. However, he reverted to a more classical view in a subsequent article published in 1909 [31]:

« [...] si à l'exemple du chimiste, qui ne peut agir sur les molécules isolées du corps qu'il étudie, nous ne pouvons interroger individuellement les fibres composantes des nerfs que nous expérimentons, nous avons néanmoins sur lui l'avantage de voir nos éléments à nous par les méthodes histologiques et de leur reconnaître ainsi certains caractères empiriques, qui les distinguent en catégorie. » ([31], p. 671)

[If as the chemist unable to act on isolated molecules from the body he studies, we cannot study individual fibres forming the nerves on which we experiment. Even so, we do have the advantage to be able to see our elements by histology and so to recognize in them some empiric characters which let us categorise them.]

However, while French physiologists unequivocally adopted the neurone doctrine and considered the nerve cell an anatomical unit, nervous functions were rather seen as relevant to the intimate nature of fibres. This idea led to the ancient refusal to attribute any specific physiological role except a trophic function to the soma of nerve cells, in accordance with the doctrine of Augustus Volney Waller (1816-1870). Energy, substance, movement, life were seen as equally scattered entities in the nervous system, which underlied non localised functions. 
Therefore, the distribution of nerve cells in the nervous system was not central. Rather, the topography of fibres and their physical interactions were considered the essential factors in nerve cell excitation.

Louis Lapicque (1866-1952), a student of Dastre and leader of French neurophysiologists between the world wars, developed these ideas into a concerted theoretical system based on single nerve studies. In accord with his purely physiological and speculative views, Lapicque adopted the synapse of Sherrington, as a physiological concept based on polarization, delay and an anatomical determinism of neurotransmission.

« [...] c'est à la synapse qu'est localisée la fonction essentielle du centre nerveux $[\ldots]$ Sherrington a donné un résumé, remarquable dans sa concision, des différences essentielles qui distinguent de la simple propagation dans un tronc nerveux le passage de l'influx par les centres, et il a montré que presque toutes ces différences peuvent se caractériser de la façon suivante : transmission intercellulaire au lieu de transmission intracellulaire $[\ldots]$ » ([32], p. 106)

[ [...] the essential function of nervous centre is localised at the synapse [...] Sherrington gave a remarkably concise summary of essential differences which distinguish simple propagation in a nervous trunk from the passage of nervous impulse through a centre and he showed almost all these differences can be characterised as so: intercellular transmission in place of intracellular transmission.]

However, Lapicque envisaged these properties not in an anatomical framework, but rather from that of the physical possibility of transmission between two nervous elements dependent on a similar excitability (chronaxie). Therefore, Sherrington's and Lapicque's views were opposed in the importance attributed to the soma and elementary fibres. Sherrington supposed that nervous impulses converged on central nerve cells, anatomically connected to afferent fibres, whose activity imposed a central delay and a polarity of nervous conduction. Conversely, Lapicque understood nervous impulse conduction as determined not only by anatomical connections of fibres, but more importantly by the tuning of physical properties controlled by higher centres, between functionally continuous elements.

Lapicque's conceptions are often presented as old dogmas established on the basis of chronaxie measurements in the early XXth century, which induced a paralysis in French physiology for over three decades [33]. It should be emphasized that Lapicque's character was of fundamental importance in this period. However, the development of a Lapicquian physiology can be traced to the rejection of the neuronal soma as a physiological element starting in the 1880 s. Lapicque later developed a grand theory of nervous functions rejecting anatomy and the neurone concept. His attitude finally led to the full dismissal of his highly speculative ideas. Thus, the functionalist attitude of Lapicque may represent an opposite extreme to Duval's programme of histophysiology.

\section{Sherrington's myographic decomposition of nerve centres and the neurone as a physiological concept (1900-1926)}

The comparison between Sherrington's and Lapicque's ideas on the neurone can be seen as a divergence from an initial criticism by physiologists of the nerve cell in the late 1880s. However, in his personal researches Sherrington created a dialogue between histology and physiology which 
focussed on specific objects and concepts, including the flexor reflex, summation and the convergence of nervous impulses. This style of research was based on a systematic topographical and functional approach of specific reflexes and on the localization of nervous properties in centres and their neuronal constituents.

Sherrington relied more on anatomy than on modern physical measurements. When Lapicque and Herbert Gasser (1888-1963) adopted oscillography in the early 1920 s to analyse specific nerve fibre properties, Sherrington used the techniques of Marey, and his follower Charles Emile François-Franck (1849-1921) to decompose elementary reflex properties. Sherrington was interested in the neurone as a principal physiological element for how it might assist his attempts to dissect the reflex centre of the flexor reflex [34]. The conjunction of the neurone theory within Sherrington's framework, as analysed by Swazey, relied on the belief that both inihibitory and facilitatory mechanisms, earlier known as Hemmung and Bahnung in the German literature, contributed to central operations of co-ordination, taking place before a common path of nerve fibres converged on an effector muscle ([35], pp. 100-101). According to the schematic demonstration of Sherrington's 1926 article, the total amount of contraction of a muscle, obtained by stimulating successively individual nerves independently, was greater than the maximum contraction of that same muscle by direct stimulation. This was interpreted as a partial occlusion of nervous impulses from different nerves converging on common motoneurones. Similarly, the facilitatory effect of a subliminal stimulation, in a given path, on the contraction obtained by stimulating another path was interpreted in terms of a central excitatory state in motoneurones. For Sherrington, neurones were the cellular basis of co-ordination in the nervous system. They were for the first time given a prime physiological importance on experimental grounds.

\section{Adrian's physiological foundation of the neurone (1926- 1929)}

Compared to Sherrington's views, the neurone concept developed in the 1920s by Adrian was more than a speculative entity. It relied on precise instrumental objectivations. However, Adrian's initial approach, following that of his teacher Keith Lucas (1879-1916), focussed on understanding the nature of nervous impulse. Adrian's physiological foundation of the neurone borrowed from the differing orientations of Sherrington and Lucas. Their programmes must be first confronted to highlight the heuristic value later emerging from their dialogue. In a sense, Adrian's approach was a convergence between one approach based on anatomical grounds and speculation, and the other grounded in spatio-physico-chemical explanations of the properties of isolated nerve axons. Comparison with France is no longer fruitful, since convergences between anatomo-clinical investigations and nerve studies in Lapicque's school focussed on medical rather than neurophysiological questions.

Both Lucas and Sherrington agreed that nerve conduction differed from the passage of nervous impulses in centres. Lucas saw conduction in nerve trunks as stereotyped and lacking properties such as inhibition, rhythms, residual discharges which enabled centres to adapt their activity ([36], p. 8). However, he did not follow Sherrington in locating such complex properties in non-nervous elements, which the Cambridge school recognised as nerve cells. Lucas felt these differences reflected ignorance of elementary mechanisms of conduction in nerve fibres ([36], p. 8) and so emphasized such studies initiated by Max Verworn 
(1863-1921) and Friedrich Wilhelm Frohlich (1879-1932).

In this perspective, Adrian's programme was aimed in the 1920 s at deriving elementary properties of single fibre activity with the idea of the possible all-ornone nature of the propagated nervous disturbance. In spite of Lucas' idea and after World War I, Adrian collaborated with Cambridge school physiologists Alexander Forbes (1882-1965), James Montrose Duncan Olmsted (1886-1956) on spinal reflexes. The convergence of an in vivo approach with recordings of elementary sensory fibre activities was necessary for both their spatial and temporal decompositions. Dissection to single fibres and the in vivo temporal dispersion of their activities were two necessary conditions to measure trains of spikes, adaptation and refractory periods in single fibres. Adrian interpreted refractory periods of different durations in two ways. First, following Lucas, long periods of refractoriness could depend on slow conduction in non-myelinated portions of a fibre, or be localised according to the Cambridge school in non-nervous elements, such as end-organs of sensory fibres [37]. Only subsequently did Adrian finally adopt the second view and localise a property measured in isolated single fibres in a motoneurone soma [38]. The comparison of single activities in sensory and motor fibres led Adrian to suppose that the essential neuronal element was perhaps not the soma itself, but rather the dendritic expansions in contact with a nervous terminal arborisation.

" The only structural factors common to the sense organ and the motor nerve cell appear to be the terminal (axonal) arborisation which links the axon of the sensory fibre with the sense organ, and that which invests the nerve cell or forms the junctional zone between its dendrites and the axons of others neurones.» ([39], p. 145)
« $[\ldots]$ the resemblance between the disharges of sense organs and of motor neurones $[. .$.$] have suggested that both are$ determined by some general property of the dendritic expansion.» ([40], p 139)

«[...] the simplest alternative is to suppose that the rhythmic discharge actually starts in the terminal arborizations of the sense organ and in some part of the motor nerve cell or its dendrites. » ([39], p. 150)

This view was developed in accord with the concept of the synapse and with the idea of chemical transmission. Adrian's microphysiology of nervous activities had thus created a neurone concept based on localisations of fibre properties in neuronal parts, within a wide theoretical framework.

Adrian's neurone concept developed further in studies on retina, where interactions between photoreceptors and dendritic arborisation of ganglion cells could be analysed topographically. Such analysis recalls that of Sherrington's on the convergence of nerve fibres on a common motoneurone pool. Adrian showed that the maximum retinal surface exposed to light from which a single ganglion cell could be excited was wider than the area of its dendritic expansion [41, 38]. Thus, light receptors and the excited nervous network beneath were converging onto individual ganglion cells. Therefore, Adrian had succeeded in defining experimentally Sherrington's common path at the cellular level.

\section{Eccles's studies on ganglia and further neuronal localizations in the Cambridge school}

The synthesis of the ideas of Adrian and Sherrington who jointly won the 1932 Nobel prize led to a wide field of inquiry which rapidly adopted oscillography for 
electrophysiological studies. The Cambridge school, tending to localize nervous properties into neurones, was exposed to American researches which aimed to distinguish fibres by their specific individual properties.

Two different implicit epistemological choices were available. Should correlations between elementary potentials and anatomy be interpreted according to distinct fibre types or to the central topography of neuronal somata. In the early 1930s, many investigators including George Holman Bishop (1889-1973), Peter Heinbecker (1895-1967), John Carew Eccles (1903-1997), Detlev Wulf Bronk (1897-1975), Jean Govaerts, David Lloyd (1911-1985), Sixto Obrador (1911-1978), José Bernardo Odoriz (1908-) and David Whitteridge (1912-1994) realized such correlations required the study of simple nervous structures such as ganglia. Bishop's 1932 paper was the first of this kind, where oscillographic potentials in ganglia were interpreted as complex spatial and temporal summations of elementary potentials from homogenous populations of fibres [42]. Eccles' first paper on ganglia adopted the same approach:

« four corresponding groups of preganglionic fibres [which] may be distinguished from one another by [...] [the] rates of preganglionic conduction, [...] thresholds, [...] refractory periods [...] Presumably the four groups of preganglionic fibres differ only in regard to size and medullation [...]» ([43], pp. 202203)

This analysis was in accords with Bishop and Heinbecker who found no sign of central properties:

« $[\ldots]$ we find no spread of response from one cell to another, no after-discharge, and no summation of preganglionnic impulses in the ganglion, although more fibers emerge from it than enter. » ([42], p. 532)
However, a controversy emerged on the interpretation of the refractory period of output compared to input fibres. Eccles showed the slow value measured by Bishop was much reduced in oxygenated and superfused ganglia. Hence, Eccles suggested its neuronal origin, in agreement with the old finding that centres were more sensitive to anoxia than nerve trunks. In spite of Rafael Lorente de Nó's (19021990) apparent dismissal of this view, based on the similarity between input and output refractory periods, Eccles and the Cambridge school relied on small differences in refractory period to support their opinion that output potentials reflected the passage of the nervous impulse through neuronal somata.

« $[\ldots]$ the absolute refractory period of the motoneurones (dendrites and body including the synapses) cannot be longer than $0.6 \mathrm{~ms}$ which is the absolutely refractory period of the stimulated fibres themselves. The present evidence neither excludes nor proves the existence of a relatively refractory period of the neurone body. It is suggested that the perikaryon functions in the same way as the muscle endplate $[\ldots] \gg([44]$, p. 288)

The Cambridge school later objectivated neurones according to correlations between the topography of slow potentials and neuronal ganglionic somata. Again, Eccles' study relied on American oscillography, and especially Gasser's studies of slow after-potentials recorded from isolated nerves. Gasser considered after-potentials resulted from molecular and metabolic states of nerve's plasma membrane. Conversely, Eccles showed that slow waves, either positive or negative, were larger when recorded closer to ganglionic neurones. Correlations between the polarity of these waves and facilitation between successive stimuli led him to suggest that slow potentials were generated inside neuronal somata, and 
reflected the central excitatory (c.e.s) or central inhibitory states (c.i.s) of Sherrington. This attitude was severely judged as a speculative localization of neuronal properties by axonologists, a group of scientists formed by Alexander Forbes (1882-1965) et Ralph Waldo Gerard (1900-1974), studying nerve properties with oscillography and including Joseph Erlanger (1874-1965), Gasser, Bishop, Heinbecker and their followers.

« [...] adequate demonstration of the character of neurone body potentials as such seems not to have been reported, nor estimates of what fraction of the total potential observed was assignable to cells. » ([45], p. 465)

Hence, Eccles' studies on ganglia were an attempt to experimentally establish concepts from the Cambridge school with the oscillographic approach of American axonology. The analysis remained speculative until a consensus emerged from later studies on spinal cord.

\section{Polemics on the neurone in oscillographic slow potentials recordings in spinal cord and oculo-motor ganglia}

Once again, Gasser made the first step when he performed localized measurements of slow potentials by oscillographic recordings on the surface of the exposed spinal cord [46]. Gasser showed slow potentials were not occluded by initial antidromic stimulation, thought to establish a refractory period inside neuronal somata. Accordingly, he could not localize slow potentials in motoneurones, but rather in secondary networks of internuncial neurones, whose activity was interpreted as a slow shift of polarity within a dipolar equivalent circuit. Gasser's interpretation was dependent on
Adrian's conceptions, but did not localize potentials precisely to specific neuronal elements. Furthermore, Gasser himself established a parallel between slow internuncial potentials and Sherrington's central excitatory state. Therefore, discussions on the c.e.s focussed on whether it represented Eccles' elementary neuronal slow potential or Gasser's and Lorente de Nó's internuncial activity.

Eccles did not pursue the question on Gasser's experimental ground, but further established his conceptions on ganglia. The axonologist Lorente de Nó further studied the involvement of internuncial neurones in oculo-motor ganglia. His initial oscillographic measurements of refractory periods had led him to adopt an aggressive attitude and a strange interpretation of nervous centres relying on old criticisms of the nerve cell, reminiscent of his histological background from Ramón y Cajal's school:

" $[\ldots]$ evidence has been forthcoming which changes the theoretical basis upon which the Oxford school based the discussion of the experimental findings." [44]

" The concept of the neurone as a nerve fibre provided with a trophic centre and two specialized endings affords satisfactory means of understanding the role of the intercellular connections within the nerves centres [...].” ([47], p. 608)

Lorente de Nó explained facilitation and the reductions in reflex latency by higher intensity stimuli by the recruitment of more direct internuncial paths. Hence, Eccles' neuronal properties were seen among axonologists as circuit properties and the specific role of individual neuronal somata was again dismissed. 


\section{Toward a consensus between American and British neurophysiologists}

From our present standpoint, earlier conflicts between neurophysiologists, who fought to localize specific electrical properties either in the axon or the soma of neurones, may seem strange. The elementary properties of electrical membranes are currently thought to be rather homogeneously distributed over the neuronal membrane, in spite of distinct distributions of specific ionic channels, receptors and some emergent electrical properties. However, physiological traditions favoured dichotomy in localizing properties in anatomical elements. Neuronal properties emerged in Adrian's analysis from non-nervous properties. This approach can be regarded as a necessary step dividing and confronting specific aspects of concepts in their genesis, before establishing more sophisticated relations between them.

Epistemological relations between somata, fibres and neuronal networks changed when Lorente de Nó and Eccles finally agreed, in the context of the polemic over electrical versus chemical neurotransmission. Both of them defended the electrical theory of neurotransmission which led Lorente de Nó to adopt a general view on nervous transmission based on the physiological individuality of the neurone, with synaptic contacts converging onto the neuronal soma. Hence, the neurone was necessarily seen as a micro-circuit of its own. Consequently, Lorente de Nó reworded his ideas according to Eccles' which he felt closer than originally thought. He made a clear parallel between his concept of partially active internuncial circuit and the Cambridge school's concepts of the motoneurone pool and the inactive subliminal fringe.
« [...] using a term introduced by the Oxford school it may be said that during activity the internuncial and motor pools become fractionated into active and inactive groups, part of the latter group constituting a subliminal fringe, the activation of which demands stimulation of another set of pathways. » ([48], p. 212)

The early polemics on Sherrington's c.e.s led to this new parallel between this concept and a theoretical state of excitation in Lorente de Nó's internuncial circuits.

«[...] the main difference between the concept of c.e.s used by the Oxford school and that of continuous stimulation by internuncial bombardment is that c.e.s was assumed to develop and accumulate within the individual neurones, while internuncial bombardment places the excitatory and facilitatory mechanisms outside of the cell. For many theoretical arguments the difference may be overlooked; in fact, the result obtained is essentially the same, whether the one or the other concept is used.» ([48], p. 328)

These convergent views were essential in the physiological construction of the neurone concept, since neuronal somata were no longer rigid loci of convergence and building of slow potentials, but also formed part of secondary neuronal circuits representing multiple sites of neuronal convergence, facilitation and subliminal excitation involved in retroactive controls. These interpretations finally led to a series of topographic electrophysiological studies on the functional organization of the spinal cord by Lloyd, Birdsey Renshaw (19111948) and Eccles. These studies were based on isolated monosynaptic reflex arcs, thus avoiding internuncial activities, and permitting the precise measurement of elementary neuronal parameters. 


\section{Berger rhythm (1929) and further questions on the neurone}

The physiological construction of the neurone was based upon measurements of patterns of central nervous activities, such as slow, often rhythmic potentials generated by populations of neurones. Large-scale oscillating activities were interpreted as a synchronization of slow elementary neuronal activities. Adrian developed such analysis on the isolated goldfish brainstem [49]. But the question was already asked when Hans Berger (1873-1941) published slow potential waves recorded from the human scalp. Hallowell Davis' (1896-1992) reaction to Berger's discovery probably reflects the most common attitude of physiologists, whether they adopted Davis' or Adrian 's view.

« I explained patiently that it must be a vibration in his equipment or other artefact because it was unthinkable that enough axons in the brain could be so synchronized in their activity as to yield such slow potentials. » ([50], p. 316)

" It thus appears that the axons of the brain have much larger potential than elsewhere, or else the record is due to nerve cells, having a higher and more protracted potential than nerve fibers give. » [51]

The discovery of the Berger rhythm did not influence oscillographic studies during 1932-1933. When Adrian discussed brain waves in his 1933 Nature article, he mentioned Max Heinrich Fischer, Alois Eduard Kornmüller (1905-1968), Samuel Howard Bartley (1901-1988), Bishop, but not Berger. Later Adrian partially changed his view when he rejected the concept of c.e.s in interpreting brain waves [52]. Nevertheless, a role of slow neuronal elementary potentials remained central.
« The rate of beating will then depend on the constitution of the cells and on nothing else. Thus the Berger rhythm is disappointingly constant, for it expresses time relations which are determined by the fundamental properties of the cells. » ([53], p. 382)

There was a crucial need for new concepts to handle assemblies of cortical neurones. Jasper was the first American neurophysiologist to reproduce data on the Berger rhythm. He dismissed Kornmüller's attempt to correlate brain rhythms with cytoarchitectonics and the temptation to return to interpretations based on closed chains of neurones. Close to Gasser, Jasper felt brain rhythms should be analysed from knowledge of single fibre activities, but he finally concluded: " it is of great importance [...] to know what the single cortical cell is doing 》 ([54], p. 326). Forbes' initial microelectrode studies on cortex had revealed slow elementary all-ornone units possibly representing individual activities from cortical somata [55-57]. In a 1948 review in Science Jasper [58] appealed for further studies of this kind.

However, Jasper's 1952 Science review [59] summarizing recent microelectrode studies showed slow brain waves had no clear correlation with single neurone activities. Elementary activities were either in phase or out of phase or uncorrelated with brain rhythms. The only valid interpretation was that Berger rhythm represented slow potentials in distal parts of neurones, linked to chemical neurotransmission, but not to the all-ornone spiking activity of the neurone. Such interpretation led to further studies on elementary dendritic potentials. A large symposium on dendrites organised by the American Society of Electroencephalographers viewed dendrites as conductive and non polarized elements, an opinion that many axonologists could not accept (1958). 
Thus, in the context of building a neurone concept based on localising slow potentials into cell parts, the Berger rhythm came into play as a peculiar slow and regular wave previously though irreducible no any single neurone activity, then theoretically accepted as a synchronisation of simple all-or-nothing neuronal potentials, before this hypothesis was finally rejected. However, the resulting polemic was profitable for the definition of the neurone, further distinguished from its axonal activity and with dendrites which emerged as independent conductive elements.

\section{The view from inside}

Extracellular studies on the neurone took advantage of monosynaptic reflexes and dissociated single neurones [60-62], but still divergences emerged in the localization of specific potentials to distinct cell parts, as illustrated by the polemics between Lloyd and Eccles (19491951) and differing ideas on dendritic conduction. The first intracellular records were made from muscle cells and giant nervous fibres by Alan Lloyd Hodgkin (1914-1998), Kenneth Stewart Cole (19001984), Howard James Curtis (1906-1972) and Gerard. Eccles records from cat motoneurones opened a new field of membrane and action potential studies on neurones in close conjunction with the complex framework of extracellular studies. Invading backpropagating action potentials recorded inside the soma was a direct proof of the old idea that spikes could spread from the axon to the soma, a view later extended to dendritic backpropagation. Synaptic potentials replaced Sherrington's c.e.s and end-plate noise [63]. Eccles' 1952 concept of the neurone [64] was a synthetic view that combined extracellular neurophysiology and borrowed extensively from the membrane physiology of the squid giant axon. Hence, intracellular recording allowed a more rigorous correlation of local potentials within anatomically defined neuronal parts and allowed definition of numerical norms of neuronal activity, such as resting membrane potential, maximum action potential depolarization and after-potentials.

More importantly, the new intracellular paradigm allowed studies on the neurone to borrow concepts and techniques from the field of membrane physiology, with the adoption of voltage-clamp, superfusion exchanges of intracellular ionic contents and the modelling of ionic permeabilities accounting for somatic and synaptic potentials. Intracellular recording was much more than a technique that opened a new field of study. It was rather an important interdisciplinary locus for conceptual and technical interactions.

\section{Concluding remarks}

This inquiry into the physiological construction of the neurone concept during the early XXth century hints at how epistemological conflicts emerge from confrontations between disciplines. Comparison of national contexts shows how boundaries between disciplines, conflicts and convergences permitted the emergence of a specific concept. Different evolutions in adopting, rejecting, or developing the neurone concept depended on complex relations between anatomy and physiology in different nations.

The interdisciplinary construction of the neurone was dependent on personal backgrounds, social relations between researchers of neighbouring disciplines. In this context, the legitimacy of histological and physiological revisions of the neurone concept changed as new approaches and techniques were developed. The early proposal of the neurone concept allowed histology to extend its functional implications from anatomical observations, which confronted physiological data on the polarization of nervous conduction. 
Sherrington borrowed from the notions of Ramón y Cajal to base his studies on the neurone concept. With his work, physiology overcame histology in its legitimacy to rectify and build the neurone concept as physiological. In France, Lapicque did not find any legitimacy with the theory of chronaxie as speculative as his opponents' histophysiological theories.

Physiological interest in the neurone concept emerged in two British schools which combined in the studies of Adrian. New instruments and measurements of single fibre activities in Sherrington's reflexology led to a new and direct objectivation of the neurone concept by convergence of ideas on all-or-nothing principle of nervous impulse, synchronization of elementary activities by converging afferent inputs on neuronal populations and inside a single neurone.

The role of converging interests from various schools, with initially opposed programmes, illustrates the necessity of social disciplinary relations in the evolution of concepts. The polemics between British physiology and American axonology highlights the heuristic value of local concepts and their re-combinations. Adversary concepts originally apparently dichotomous may eventually be seen to converge in descriptions of identical elements, as in the synthesis of the ideas of Lorente de Nó and Eccles on one hand and those of Lloyd and Eccles on the other.

Finally, the cross-disciplinary transfer of techniques in the development of intracellular recording permitted a major paradigm shift that did not overthrow the conceptual framework from extracellular studies. Instead extracellular potential data could be re-interpreted in the light of novel and robust concept systems based upon direct measurements and the migration of techniques and ideas from fields such as membrane biophysics.
In summary, the physiological construction of the neurone concept has been the site of intense interactions between subdisciplines from numerous points of view including social relations, instrumental progress, interactions between distinct disciplinary patterns of concepts, and the redefinition of fields of enquiry.

\section{Acknowledgements}

The author wishes to thank Dr. Richard Miles for careful reading of the manuscript.

References

[1] W. Waldeyer-Hartz, Ueber einige neuere Forschungen im Gebiete der Anatomie des Centralnervensystems, Deutsche medicinische Wochenschrift, Berlin, 17 (1891) 1213-1218, 1244-1246, 1287-1289, 1331-1332, 1350-1356.

[2] C. Bernard Claude, Leçons sur la physiologie et la pathologie du système nerveux, Baillère, Paris, 1858.

[3] L. Ranvier, Des tubes nerveux en $\mathrm{T}$ et de leurs relations avec les cellules ganglionnaires, C.R. Académie des Sciences 81 (1875) 1274-1276.

[4] M. Foster, A text book of physiology, $5^{\text {th }}$ ed., Macmillan, London, 1888.

[5] C. Robin, Anatomie et physiologie cellulaires, Baillère, Paris, 1873.

[6] M. Duval, Cours de Physiologie, Baillère, Paris, 1892.

[7] M. Duval, Preface, in: S. Ramón y Cajal, Les nouvelles idées sur la structure du système nerveux chez l'homme et les vertebras, Reinwald, Paris, 1895.

[8] A. Prenant, Review of O. Hertwig's book entitled La Cellule et les tissues, Revue Générale des Sciences Pures et Appliquées, 5 (1894) 425-426.

[9] A. Prenant, Les théories du systèmes nerveux, Revue Générale des Sciences Pures et Appliquées, 11 (1900) 13-30 ; 69-82.

[10] R. Legendre, Thèse présentée à la Faculté des Sciences de Paris, Masson, Paris, 1909.

[11] M. Duval, Hypothèses sur la physiologie des centres nerveux; théorie histologique du sommeil, C.R. Société de Biologie, 24 (1895) 74-77.

[12] W. Turner, The cell theory, past and present, J. Anat. Physiol., 24 (1890) 253-287.

[13] A. Sedgwick, On the inadequacy of the cellular theory of development, and on the early development of nerves, particularly of the third nerve and of sympathetic in Elasmobranchii, Quart. J. Microscopical. Sci., 37 (1894) 87102. 
[14] G. C. Bourne, A criticism of the cell theory; being an asnwer to Mr. Sedgwick's article on the inadequacy of the cellular theory of development, Quart. J. Microscopical. Sci., 39 (1895) 137.

[15] R. D. French, Some concepts of nerve structure and function in Britain, 1875-1885: background to Sir Charles Sherrington and the synapse concept, Med. Hist. 14 (1970) 154-65.

[16] E. P. Sparrow, S. Finger, Edward Albert Schafer (Sharpey-Schafer) and his contributions to neuroscience: commemorating of the 150th anniversary of his birth, J. Hist. Neurosci. 10 (2001) 41-57.

[17] E. A. Schäfer, Observations on the nervous system of Aurelia aurita. Philosophical Transactions of the Royal Society of London, 169 (1878) 563-575.

[18] J. Cohnheim, Virchow's Arch, 38 (1866)

[19] L. Ranvier, Sur les terminaisons dans les lames électriques de la Torpille, C.R. Acad. Sci. 81 (1875) 1276-1278.

[20] L. Ranvier, De la terminaison des nerfs dans les corpuscules du tact, C.R. Acad. Sci. 85 (1877) 1020-1023.

[21] L. Ranvier De la méthode de l'or et de la terminaison des nerfs dans le muscle lisse. C.R. Acad. Sci. 86 (1878) 1142-1144.

[22] G. L. Geison, Michael Foster and the Cambridhe school of Physiology, Princeton University Press, Princeton, 1978.

[23] G. Romanes, Jelly-fish, Star-fish and Seaurchins, being a research on primitive nervous systems, Kegan Paul, Trench and Co., London, 1885.

[24] E. A. Schäfer, The nerve cell considered as the basis of neurology, Brain, 16 (1893) 134-169.

[25] W. Gibson, 1985 Herbert Jasper lecture. Pioneers in neurosciences: the Sherrington era, Can. J. Neurol. Sci. 13(1986) 295-300.

[26] S. Ramón y Cajal, La fine structure des centres nerveux: the Croonian Lecture, Proc. Roy. Soc. Lond., 55 (1894) 443-468.

[27] E. M. Tansey, Not committing barbarisms: Sherrington and the synapse, 1897, Brain Res. Bull., 44 (1997) 211-212.

[28] C. U. M. Smith, Sherrington's legacy: evolution of the synapse concept, 1890s-1990s, J. Hist. Neurosci., 5 (1996) 43-55.

[29] C. S. Sherrington, Double (antidrome) conduction in the central nervous system, Proc. Roy. Soc. Lond. 61 (1897) 243-246.

[30] G. Berlucchi, Some aspects of the history of the law of dynamic polarization of the neuron. From William James to Sherrington, from Cajal and van Gehuchten to Golgi, J. Hist. Neurosci. 8 (1999) 191-201.

[31] J. P. Morat, La loi de Magendie; le temps physiologique, Rev. Gen. Sci. P. A., 20 (1909) 669-675.
[32] L. Lapcique, Principe pour une théorie du fonctionnement nerveux élémentaire. Rev. Gen. Sci P. A. 21 (1910) 103-117.

[33] J. G. Barbara, Les heures sombres de la Neurophysiologie à Paris (1909-1939), Lettre des Neurosciences, 29 (2005) 3-5.

[34] S. Cooper, D. E. Denny Brown, C. S. Sherrington, Reflex fractionation of a muscle, Proc. Roy. Soc. B, 100 (1926) 448-462.

[35] J. P. Swazey, Reflexes and motor integration, Harvard University Press, Cambridge, 1969.

[36] K. Lucas, The conduction of nervous impulse, Longmans Green, London, 1917.

[37] E. D. Adrian, The impulses produced by sensory nerve-endings. Part I, J. Physiol. Lond., 61 (1926) 151-171.

[38] E. D. Adrian, The discharge of impulses in motor nerve fibres. Part I., J. Physiol. Lond., 66 (1928) 80-101.

[39] E. D. Adrian, D.W. Bronk, The discharge of impulses in motor nerve fibres. Part II, J. Physiol. Lond., 67 (1929) 119-151.

[40] E. D. Adrian, K. Umrath, The impulse discharge from the pacinian corpuscule, J. Physiol. Lond., 68 (1929) 139-154.

[41] E. D. Adrian. The action of light on the eye. Part I, J. Physiol. Lond., 63 (1927) 378-414, Part II, 64 (1927) 279-301, Part III, 65 (1928) 273-298.

[42] G. Bishop, P. Heinbecker, A functional analysis of the cervical sympathetic nerve supply to the eye, Am. J. Physiol., 100 (1932) 519-532.

[43] J.C. Eccles, The action potential of the superior cervical ganglion, J. Physiol. Lond., 85 (1935) 179-206.

[44] R. Lorente de Nó, The refractory period of the motoneurones, Am. J. Physiol., 111 (1935) 283-288.

[45] G. H. Bishop, Interpretation of potentials led from the cervical sympathetic ganglion of the rabbit, J. Cell. Comp. Physiol., 8 (1936) 465477.

[46] H. S. Gasser, H.T. Graham, Potentials produced in the spinal cord by stimulation of dorsal roots, Am. J. Physiol., 103 (1932) 303320.

[47] R. Lorente de Nó, The effect of an antidromic impulse on the reponse of the motoneurone, Am. J. Physiol., 112 (1935) 595-609.

[48] R. Lorente de Nó, Analysis of the activity of chains of internuncial neurons, J. Neurophysiol., 1 (1938) 207-244.

[49] E. D. Adrian, Potential changes in the isolated brain stem of the goldfish, J. Physiol., 71 (1931) 121-134.

[50] H. Davis, Crossroads on the Pathways to discovery. In The Neurosciences: Paths of discovery, MIT Press, Cambridge, 1975. 
[51] G. H. Bishop, H. Bartley, Electrical activity of the cortex as compared to the action potential of excised nerve, Proc. Soc. Exp. Biol. Med., 29 (1932) 698-699.

[52] E. D. Adrian, B.H.C Matthews, The interpretation of potential waves in the cortex, J. Physiol., 81 (1934), 440-471.

[53] E. D. Adrian, B. H. C Matthews, The Berger rhythm: potential changes from the occipital lobes in man, Brain, 57 (1934) 355-385.

[54] H. H. Jasper, Cortical excitatory state and synchronism in the control of bioelectric autonomous rhythms, Cold Spring Harb. Symp. Quant. Biol., 4 (1936) 320-338.

[55] A. Forbes, B. Renshaw, B. Rempel, Units of electrical activity in the cerebral cortex, Am. J. Physiol., 119 (1937) 309-310.

[56] B. Renshaw, A. Forbes, C. Drury, Electrical activity with microelectrodes from the hippocampus, Am. J. Physiol., 123 (1938) 169170.

[57] B. Renshaw, A. Forbes, B. R. Morison, Activity of isocortex and hippocampus: electrical studies with licro-electrodes, J. Neurophysiol., 3 (1940) 74-105.

[58] H. H. Jasper, Charting the sea brain waves, Science, 108 (1948) 433-437.

[59] H. H. Jasper, Brain waves and unit discharge in cerebral cortex, Science, 116 (1952) 656657.

[60] G. Svaetichin, Electrophysiological investigations on single ganglion cells. Part I: Low resistance micro-electrodes, Acta Physiol. Scand., 24 (1951) 5-13.

[61] G. Svaetichin, Electrophysiological investigations on single ganglion cells. Part II: A combination of microscopes and micromanipulators for electrophysiological investigations on single cells. Acta Physiol. Scand., 24 (1951) 15-22.

[62] G. Svaetichin, Electrophysiological investigations on single ganglion cells. Part III: Analysis of action potentials from single spinal ganglion cells, Acta Physiol. Scand., 24 (1951) 23-57.

[63] P. Fatt, B. Katz, An analysis of the end-plate potential recorded with an intra-cellular electrode, J. Physiol., 115 (1951) 320-370.

[64] J. C. Eccles. The electrophysiological properties of the motoneurone, Cold Spring Harb. Symp. Quant. Biol., 17 (1952) 175-183. 